\title{
Investigation of Relationship between Udder Morphology, Lactation Traits and Milk Components in Morkaraman and Awassi
}

\author{
Morkaraman ve İvesi Koyunlarında Meme Morfolojisi, Laktasyon Özellikleri ve Süt \\ Bileşenleri Arasındaki İlişkinin Araştırılması
}

\author{
Selçuk ÖZYÜREK* \\ Erzincan Binali Yıldırım Üniversitesi, Çayırlı Meslek Yüksekokulu, Veterinerlik Bölümü, 24100, Erzincan, Türkiye
}

• Geliş tarihi / Received: 07.10.2019 • Düzeltilerek geliş tarihi / Received in revised form: 13.12.2019 • Kabul tarihi / Accepted: 28.12 .2019

\begin{abstract}
In this study, it was aimed to determine the relationship between lactation traits, milk components and udder morphology in Morkaraman which accounts for approximately $21 \%$ of sheep raised in Turkey and was also used by some breeders for milk yield and Awassi sheep. 34 Morkaraman and 32 Awassi sheep were used in this study. Udder measurements were taken once in the middle lactation period (50-65 days of lactation) 2 hours before milking. Electronic caliper was used for measurements. Milk samples were taken every 15 days after birth to determine lactation traits and milk composition. While breed had statistically significant effect on lactation milk yield and lactation length, age had statistically significant effect on all of lactation traits $(\mathrm{p}<0.05)$. Breed and udder type had no statistical effect on any milk component. $23.5 \%$ of Morkaraman and 25\% of Awassi have type I udder, while the others have type III udder. In contrast to Morkaraman, positive correlation was found between udder circumference and both lactation milk yield and daily average milk yield and also between udder lenght and both lactation milk yield and daily average milk yield in Awassi. There was more correlation between udder traits and lactation characteristics in Awassi compared to Morkaraman. Although udder type had no significant effect on lactation traits, it was determined that type I udder may be more suitable for machine milking in terms of udder size. New studies on the rate of milking from the alveoli and cistern area in machine milking are recommended.
\end{abstract}

Keywords: Lactation, Milk components, Udder Traits, Udder Type

\section{$\ddot{O} z$}

Çalışmada Türkiye koyun varlı̆̆ının yaklaşık \%21'ini oluşturan ve bazı yetiştiricilerin süt verim yönünde de kullandı̆̆ Morkaraman ırkı ile islah edilmemiş İesi koyunlarında laktasyon özellikleri ile süt bileşenlerinin meme morfolojisi ile ilişkisini belirlemek amaçlanmıştır. Çalışmada 34 baş Morkaraman ve 32 baş İvesi ırkı koyun kullanılmıştır. Meme ölçüleri laktasyonun ortasında (laktasyonun 50-65. günleri) bir kere olmak üzere sağımdan 2 saat önce alınmıştır. Ölçümlerin alınmasında elektronik kumpas kullanılmıştır. Süt bileşiminin belirlenmesi amacıyla doğumdan sonra her 15 günde bir süt numuneleri alınmıştır. Irk, laktasyon süt verimi ve laktasyon süresi üzerinde, yaş ise tüm laktasyon özellikleri üzerinde istatistiki olarak önemli etkiye sahip olmuştur $(p<0.05)$. Meme tipi hem laktasyon özellikleri hem de süt bileşenleri üzerinde önemli bir etkiye sahip olmamıştır. Morkaraman ırkının \%23.5'i ve Ivesi ırkının ise \%25'i tip I memeye sahipken geri kalanlart tip III memeye sahiptir. Meme çevresi ve meme uzunluğu Ivesi ırkında daha büyük bulunurken, săg ve sol meme uzunluğu Morkaraman ırkında daha uzun bulunmuştur. Morkaraman ırkının aksine İvesi ırkında meme çevresi ile laktasyon süt verimi ve günlük ortalama süt verimi arasında ayrıca meme uzunluğu ile laktasyon süt verimi ve günlük ortalama süt verimi arasında pozitif korelasyon belirlenmiştir. Ivesi ırkında Morkaraman ırkina nazaran meme özellikleri ile laktasyon özellikleri arasında daha fazla pozitif korelasyon tespit edilmiştir. Meme tipi laktasyon özellikleri üzerinde önemli bir etkiye sahip olmamamsına rağmen meme ölçüleri açısından meme I tipinin makine să̆ıma daha uygun olabileceği belirlenmiştir. Makineli sağımda alveol ve cistern alandan sütün gelme hızı üzerine yeni çalışmaların yapılması tavsiye edilmektedir.

Anahtar kelimeler: Laktasyon, Süt Bileşeni, Meme Özellikleri, Meme Tipi

*Selçuk ÖZYÜREK; sozyurek@erzincan.edu.tr, Tel: (0446) 31135 15, orcid.org/0000-0001-6650-1017 


\section{Introduction}

As of 2018, Turkey has a total of 35 million 194 thousand sheep. According to TurkStat, while the number of milking sheep was 13637 thousand heads in 2002 and 657 thousand tons of milk was produced from these sheep, 1446412 tons of milk was produced from 18820 thousand heads of sheep in 2018. While the average lactation milk yield per sheep in 2002 was abouth $48 \mathrm{~kg}$, it increased to abouth $77 \mathrm{~kg}$ in 2018. Despite the increase in sheep milk production, the share of sheep in total milk production (22 043 thousand tons in 2018) decreased from $7.8 \%$ in 2002 to $6.5 \%$ in 2018 (URL-1, 2019).

Although the first studies on the relationship between udder characteristics and milking performance began in the 1970s (Sagi and Morag, 1974), engineering development in milking systems in recent years has increased the interest in the morphology of sheep udder (Makovicky et al. 2014). Many definitions and studies have been conducted in terms of both linear scoring of the udder and udder types (Epstein 1985; de la Fuenta et al. 1996). The anatomical structure of the udder is important for the lamb to be able to suck the milk in lamb breeding (Kaygisız ve Dag, 2017). Udder morphology is also important for milk yield and production, milk composition and machine milking (Kominakis et al. 2009, Makovicky et al. 2017). The distinction between the udder lobes and sinus and vertical teats are important for machine milking in sheep. (Unal et al. 2008a). In addition, positive and significant correlations have been reported between udder type and milk yield (Kaygisiz and Dag, 2017). In Turkey, especially in the last decade, there have been many studies examining udder morphology and the relationship between udder morphology and milk yield and investigating the suitability of sheep for machine milking (Dogan et al., 2013; Altincekic et al., 2011; Akdag et al., 2018; Kaygisiz and Dag, 2017; Unal et al., 2008a; Unal et al. 2008b). The Morkaraman used in the study constitutes approximately $21 \%$ of the country sheep. It is also the dominant indigenous breed of the Eastern Anatolia Region. The Awassi are bred South Eastern Anatolia and Çukurova in Turkey. In this study, we aimed to determine the relationship between lactation traits, milk components and udder morphology in Morkaraman and unimproved Awassi sheep.

\section{Materials and Methods}

The study was carried out in 2018 at Atatürk University, Faculty of Agriculture, Research and
Application Farm. 34 Morkaraman and 32 Awassi sheep were used in this study. Birthing started on 02.04.2018 and were completed on 19.04.2018. Lambs were weaned at the end of May. Until the weaning date, the sheep were housed together with the lambs. Then sheep were sent to the pasture between 07:00-17:00 and $0.2 \mathrm{~kg} /$ concentrate feed was given during the milking in addition to the pasture.

Udder measurements were taken once in the middle lactation period (50-65 days of lactation) 2 hours before milking (Dzidic et al. 2004). Udder circumference, udder length, distance between teat and ground, height at rump, udder width, teat length, teat diameter, distance between teats, udder depth were taken for determining the sheep's udder morphology (Altincekic and Koyuncu 2011). Electronic caliper was used for measurements. The type of udder in sheep was determined as Epstein (1985) and Doğan ve ark. (2013) reported (Figure 1.). However, only the I, III, IV and VI. udder types were found. Ewes that had IV and VI udder types were not used in the study because there were 4 in total.

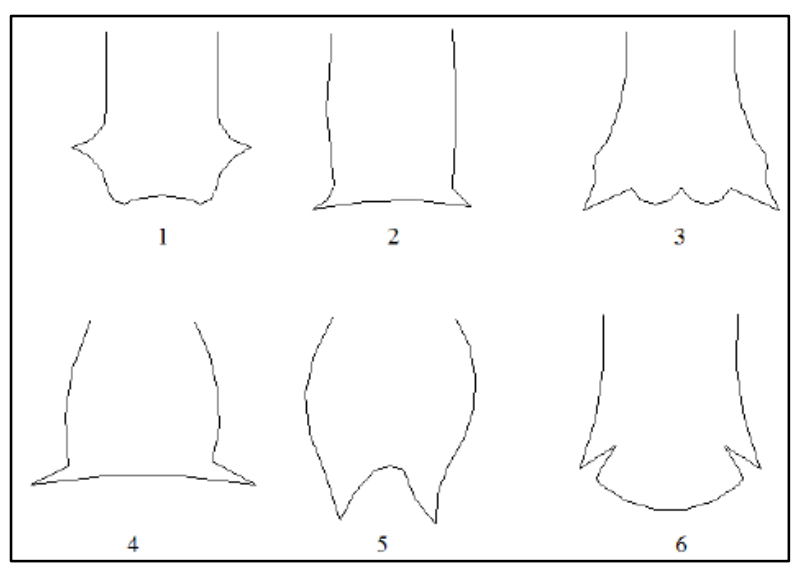

Figure 1. Types of udder in ewe (Epstein 1985)

The sheep were milked once a day with a bucket fixed milking unit at 18:00. Milking controls were repeated every 15 days. Milk weighing was done with a balance sensitive to $1 \mathrm{mg}$. Milking controls for each sheep were continued until daily milk yield was below $50 \mathrm{~g}$. The time from birth to end of lactation is calculated as lactation length (LL). The lactation milk yield was calculated using daily milk yields determined by milking controls. Trapeze II method was used to determine lactation milk yield (LMY) (Yakan 2012).

Milk samples were taken every 15 days after birth to determine the milk composition. The milk samples were placed in $50 \mathrm{ml}$ plastic tubes and stored at +4 degrees and milk composition 
analysis (fat, non-fat, protein, lactose and ash) was performed with Boeco Lac milk composition analyzer. The data were first transferred to Microsoft Excel 2010 and then SPSS 17.0 (SPSS, 2005) package program was used with General Linear Model method and Duncan multiple comparison test was used for multiple comparisons.

In the analysis of lactation traits, milk composition and udder characteristics;

$\mathrm{Y}_{\mathrm{ijk} \mathrm{l}}=\mu+_{\mathrm{ai}}+\mathrm{b}_{\mathrm{j}}+\mathrm{c}_{\mathrm{k}}+\mathrm{e}_{\mathrm{ijkl}}$

In model;

$\mathrm{Y}_{\mathrm{ijkl}}$ : Lactation milk yield, lactation length, daily average milk yield and milk composition,

$\mu$ : Expected average,

$\mathrm{a}_{\mathrm{i}}$ : Effect of genotype ( $\mathrm{i}=2$; Morkaraman=1, Awassi=2)

$b_{j}$ : Effect of age $(j=4 ; 2=1,3=2,4=3$ and $5=4)$

$c_{\mathrm{k}}$ : Effect of udder type $(\mathrm{k}=2 ; 1=1$ and $3=3)$

$\mathrm{e}_{\mathrm{ijkl}}$ : residual error.

\section{Results and Discussion}

In this study, the average lactation milk yield, lactation length and average daily milk yield were $32.71 \pm 8.4 \mathrm{~kg}, 88.93 \pm 7.1$ days and $367.18 \pm$ $46.7 \mathrm{~g}$ for Morkaraman, respectively and were $47.99 \pm 9.5 \mathrm{~kg} 130.0 \pm 8.02$ days and $348.92 \pm 52.5 \mathrm{~g}$ for Awassi, respectively. The lactation milk yield obtained for Awassi was lower than the values reported by Y1ldiz and Yildiz, (2002), Gursu and Aygun (2014), Ustuner and Ogan (2013), Alkass and Akreyi (2015). Also, the lactation milk yield found for Morkaraman was lower than the results of Kuçuk et al. (2000), Ozbey and Akcan (2000), Kirmizibayrak et al. (2005). Talafha and Ababneh (2011) reported that Awassi raised under extensive conditions in the Middle East have a milk yield of 40-60 kg during 150 days lactation period. This result is similar to the result obtained in the study. One reason for the low milk yield of Awassi can be that it was the only a milking per day.

While breed had statistically significant effect on lactation milk yield and lactation length, age had statistically significant effect on all of lactation traits $(\mathrm{p}<0.05)$. Breed and udder type had no statistical effect on any milk component. However, age had a significant effect on milk components except ratio of fat $(\mathrm{p}<0.05)$. In this study, the ratio of fat found in Morkaraman was higher than Macit and Aksoy (1996); Celik and Özdemir (2003); Y1lmaz et al. (2011). Also, the ratio of fat found in Awassi was higher than Macit and Aksoy (1996) Sahan et al. (2005) Al-Jund1 (2010). The mean value of lactation length was $88.93 \pm 7.1$ days for Morkaraman and $130.05 \pm 8.02$ days for Awassi, and this difference was statistically significant $(p<0.05)$. Although the lactation length in the Awassi was higher than the Morkaraman, it was found to be lower than the other studies carried out with the Awassi (Ozbey and Akcan, 2000; Seker et al., 2000; Kaygsiz and Dag, 2017).

$23.5 \%$ of Morkaraman and 25\% of Awassi have I type udder, while the others have III type udder. Dag and Ugur (2004) reported that the ratio of I type udder was $74.18 \%$ in unimproved Awassi. Kaygisiz and Dag (2017) reported that the ratios of I, II, III, IV and VI types udder were $31 \%, 1 \%$, $42 \%, 3 \%$ and $23 \%$ respectively, also V type udder was not found. For Bafra breed, Unal et al. (2008a) reported that the most common udder type (43\%) was type III udder that has lobes with separate and vertical extending teats. Dogan et al. (2013) in Anatolian Merino sheep, I, II, III, IV, and VI udder types were found to be $22.0 \%$, $20.3 \%, 22.0 \%, 16.9 \%$ and $18.6 \%$ respectively, also V udder type was never encountered. Similar to the results of this study, Kukovics et al. (2006) reported that the most common udder type was III udder type in the Awassi. Udder type had no significant effect on both lactation traits and milk components. The reason that milk components were not affected by udder type may be due to the major effect of nutrition on milk components. Kocak et al. (2018) for both lactation properties and milk composition in Pirlak; Akdag et al. (2018) only for milk composition (except lactose) in Karayaka reported similar results with this study, while Dogan et al. (2013) and Kaygisiz and Dag (2017) reported different results.

While breed has statistically significant effect on teat length (right) $(\mathrm{p}<0.01)$, teat length (left), udder circumference, udder length $(\mathrm{p}<0.05)$; udder type only has significant effect on udder circumference, udder length and height at rump $(\mathrm{p}<0.05)$. When it can be looked age, it has significant effect only on udder length and height at rump $(\mathrm{p}<0.05)$. The mean udder circumference was $34.47 \pm 0.8$ and $37.61 \pm 0.9 \mathrm{~cm}$ for Morkaraman and Awassi, respectively. In a different study conducted by Ozyurek et al. (2018), the udder circumference was $36.08 \pm 0.58$ for Morkaraman and 35.32 \pm 0.97 for Awassi. Udder circumference and udder length were found to be higher in the Awassi while right and left udder lengths were found to be longer in Morkaraman. 
Table 1. The least square means and standard errors for some lactation traits and milk componenets

\begin{tabular}{lccccccccc}
\hline \multirow{2}{*}{ Factors } & & LMY $(\mathbf{k g})$ & $\mathbf{L L}$ & DMY (g) & Fat (\%) & SNF (\%) & $\begin{array}{c}\text { Protein } \\
(\%)\end{array}$ & $\begin{array}{c}\text { Lactose } \\
(\%)\end{array}$ & Ash (\%) \\
\cline { 2 - 10 } & $\boldsymbol{\mu}$ & $40.94 \pm 6.4$ & $111.07 \pm 5.4$ & $357.3 \pm 35.5$ & $7.20 \pm 0.2$ & $9.21 \pm 0.1$ & $3.01 \pm 0.1$ & $5.30 \pm 0.1$ & $0.88 \pm 0.0$ \\
\hline Breed & $\mathbf{n}$ & $*$ & $*$ & $\mathrm{~ns}$ & $\mathrm{~ns}$ & $\mathrm{~ns}$ & $\mathrm{~ns}$ & $\mathrm{~ns}$ & $\mathrm{~ns}$ \\
\hline $\mathrm{M}$ & 34 & $32.71 \pm 8.4$ & $88.93 \pm 7.1$ & $367.18 \pm 46.7$ & $7.12 \pm 0.3$ & $9.18 \pm 0.2$ & $3.01 \pm 0.1$ & $5.28 \pm 0.1$ & $0.88 \pm 0.0$ \\
$\mathrm{~A}$ & 32 & $47.99 \pm 9.5$ & $130.05 \pm 8.02$ & $348.92 \pm 52.5$ & $7.26 \pm 0.4$ & $9.23 \pm 0.2$ & $3.01 \pm 0.1$ & $5.31 \pm 0.1$ & $0.89 \pm 0.0$ \\
\hline Age & $*$ & $*$ & $*$ & $\mathrm{~ns}$ & $*$ & $*$ & $*$ & $*$ \\
\hline 2 & 18 & $34.93 \pm 12.4^{\mathrm{a}}$ & $103.03 \pm 10.5^{\mathrm{b}}$ & $328.6 \pm 68.9^{\mathrm{a}}$ & $7.57 \pm 0.5$ & $9.62 \pm 0.3^{\mathrm{b}}$ & $3.15 \pm 0.1^{\mathrm{b}}$ & $5.54 \pm 0.1^{\mathrm{b}}$ & $0.92 \pm 0.0^{\mathrm{b}}$ \\
3 & 16 & $32.59 \pm 12.4^{\mathrm{a}}$ & $106.57 \pm 10.4^{\mathrm{b}}$ & $302.0 \pm 68.4^{\mathrm{a}}$ & $7.54 \pm 0.5$ & $8.75 \pm 0.2^{\mathrm{a}}$ & $2.83 \pm 0.1^{\mathrm{a}}$ & $5.07 \pm 0.1^{\mathrm{a}}$ & $0.84 \pm 0.0^{\mathrm{a}}$ \\
4 & 20 & $47.68 \pm 11.1^{\mathrm{b}}$ & $96.43 \pm 9.3^{\mathrm{a}}$ & $452.5 \pm 61.2^{\mathrm{ab}}$ & $7.45 \pm 0.4$ & $8.83 \pm 0.2^{\mathrm{ab}}$ & $2.86 \pm 0.2^{\mathrm{ab}}$ & $5.11 \pm 0.1^{\mathrm{ab}}$ & $0.85 \pm 0.0^{\mathrm{ab}}$ \\
$5+$ & 12 & $50.55 \pm 15.0^{\mathrm{b}}$ & $140.94 \pm 12.6^{\mathrm{c}}$ & $355.6 \pm 82.9^{\mathrm{b}}$ & $6.09 \pm 0.6$ & $9.47 \pm 0.3^{\mathrm{ab}}$ & $3.17 \pm 0.1^{\mathrm{ab}}$ & $5.39 \pm 0.2^{\mathrm{ab}}$ & $0.91 \pm 0.0^{\mathrm{ab}}$ \\
\hline Udder & & $\mathrm{ns}$ & $\mathrm{ns}$ & $\mathrm{ns}$ & $\mathrm{ns}$ & $\mathrm{ns}$ & $\mathrm{ns}$ & $\mathrm{ns}$ & $\mathrm{ns}$ \\
\hline type & & & & & & & & & \\
\hline 1 & 16 & $42.64 \pm 12.45$ & $115.82 \pm 10.4$ & $365.79 \pm 68.7$ & $6.75 \pm 0.45$ & $9.03 \pm 0.25$ & $2.97 \pm 0.09$ & $5.18 \pm 0.1$ & $0.87 \pm 0.0$ \\
3 & 50 & $39.87 \pm 70.01$ & $108.11 \pm 5.9$ & $352.07 \pm 38.7$ & $7.66 \pm 0.27$ & $9.31 \pm 0.14$ & $3.04 \pm 0.05$ & $5.37 \pm 0.2$ & $0.89 \pm 0.0$ \\
\hline
\end{tabular}

M: Morkaraman, A: Awassi, LMY: Lactation Milk Yield, LL: Lactation length, DMY: Daily milk yield, SNF: Solid non fat; Means with different superscript in each column ( $a, b, c)$ differ significantly; ns=not significant. *: $\mathrm{P}<0.05$

Table 2. The least square means and standard errors for udder measurements $(\mathrm{cm})$

\begin{tabular}{|c|c|c|c|c|c|c|c|c|c|c|c|c|}
\hline Factors & & UC & UL & DTG & HR & UW & TL (right) & $\begin{array}{l}\text { TL } \\
\text { (left) }\end{array}$ & $\begin{array}{c}\text { TD } \\
\text { (right) }\end{array}$ & $\begin{array}{l}\text { TD } \\
\text { (left) }\end{array}$ & DT & UD \\
\hline & $\mu$ & $36.16 \pm 0.6$ & $22.65 \pm 0.4$ & $28.29 \pm 0.6$ & $70.90 \pm 0.6$ & $10.73 \pm 0.3$ & $1.65 \pm 0.04$ & $1.66 \pm 0.08$ & $1.43 \pm 0.04$ & $1.42 \pm 0.03$ & $12.22 \pm 0.4$ & $11.89 \pm 0.4$ \\
\hline Breed & $\mathbf{n}$ & $*$ & * & ns & ns & ns & $* *$ & $*$ & ns & ns & ns & ns \\
\hline M & 34 & $34.47 \pm 0.8$ & $20.96 \pm 0.5$ & $29.67 \pm 0.7$ & $71.46 \pm 0.8$ & $10.04 \pm 0.4$ & $1.87 \pm 0.05$ & $1.91 \pm 0.11$ & $1.49 \pm 0.06$ & $1.49 \pm 0.04$ & $12.08 \pm 0.5$ & $11.61 \pm 0.5$ \\
\hline A & 32 & $37.61 \pm 0.9$ & $24.10 \pm 0.6$ & $27.11 \pm 0.8$ & $70.42 \pm 1.0$ & $11.33 \pm 0.4$ & $1.47 \pm 0.06$ & $1.46 \pm 0.12$ & $1.38 \pm 0.07$ & $1.36 \pm 0.05$ & $12.33 \pm 0.5$ & $12.13 \pm 0.5$ \\
\hline Age & & $*$ & $*$ & ns & ns & ns & ns & ns & ns & $*$ & $*$ & ns \\
\hline 2 & 18 & $35.7 \pm 1.2^{\mathrm{a}}$ & $21.57 \pm 0.8^{\mathrm{a}}$ & $28.87 \pm 1.1$ & $69.65 \pm 1.3$ & $11.78 \pm 0.6$ & $1.91 \pm 0.08$ & $1.31 \pm 0.17$ & $1.34 \pm 0.08$ & $1.27 \pm 0.06^{\mathrm{a}}$ & $10.86 \pm 0.7^{\mathrm{b}}$ & $10.89 \pm 0.7$ \\
\hline 3 & 16 & $33.98 \pm 1.2^{\mathrm{a}}$ & $23.75 \pm 0.8^{b}$ & $26.97 \pm 1.2$ & $71.56 \pm 1.3$ & $8.87 \pm 0.6$ & $1.39 \pm 0.08$ & $1.33 \pm 0.16$ & $1.33 \pm 0.08$ & $1.24 \pm 0.06^{\mathrm{a}}$ & $10.23 \pm 0.7^{\mathrm{a}}$ & $10.43 \pm 0.7$ \\
\hline 4 & 20 & $35.50 \pm 1.1^{\mathrm{a}}$ & $21.76 \pm 0.7^{\mathrm{a}}$ & $29.65 \pm 1.0$ & $71.43 \pm 1.2$ & $10.13 \pm 0.5$ & $1.71 \pm 0.07$ & $1.68 \pm 0.15$ & $1.36 \pm 0.07$ & $1.36 \pm 0.05^{\mathrm{b}}$ & $12.12 \pm 0.6^{\mathrm{a}}$ & $11.68 \pm 0.6$ \\
\hline $5+$ & 12 & $39.62 \pm 1.5^{\mathrm{b}}$ & $23.86 \pm 1.0^{\mathrm{b}}$ & $27.47 \pm 1.4$ & $71.38 \pm 1.6$ & $11.81 \pm 0.7$ & $1.52 \pm 0.10$ & $1.52 \pm 0.20$ & $1.33 \pm 0.10$ & $1.34 \pm 0.08^{\mathrm{b}}$ & $12.11 \pm 0.9^{\mathrm{a}}$ & $12.23 \pm 0.9$ \\
\hline $\begin{array}{l}\text { Udder } \\
\text { type }\end{array}$ & & ns & $*$ & ns & $*$ & ns & ns & ns & ns & ns & ns & ns \\
\hline 1 & 16 & $36.55 \pm 1.2$ & $24.25 \pm 0.8$ & $28.65 \pm 1.1$ & $72.75 \pm 1.3$ & $10.82 \pm 0.6$ & $1.75 \pm 0.08$ & $1.71 \pm 0.16$ & $1.55 \pm 0.08$ & $1.52 \pm 0.06$ & $13.36 \pm 0.7$ & $12.37 \pm 0.7$ \\
\hline 3 & 50 & $35.92 \pm 0.71$ & $21.65 \pm 0.4$ & $28.06 \pm 0.6$ & $69.75 \pm 0.7$ & $10.680 \pm 0.3$ & $1.59 \pm 0.04$ & $1.64 \pm 0.09$ & $1.36 \pm 0.05$ & $1.36 \pm 0.03$ & $11.50 \pm 0.4$ & $11.59 \pm 0.4$ \\
\hline
\end{tabular}

M: Morkaraman, A: Awassi, UC: Udder Circumference, UL: Udder length, DTG: Distance between teat and ground, HR: Height at rump, UW: Udder width, TL (right): Teat length, TL(left): Teat length, TD(right): Teat diameter, TD(left): Teat diameter, DT: Distance between teats, UD: Udder depth; Means with different superscript in each column (a, b, c) differ significantly; ns=not significant. *: $\mathrm{P}<0.05$

Udder circumference was found for the Awassi breed is $2.05 \mathrm{~cm}$ lower than the Israeli sheep (Prpic et al. 2013) and $3.39 \mathrm{~cm}$ lower than the Suffolk (Martinez et al. 2011). The udder circumference found lower for the Morkaraman than the result of Kirmizibayrak et al. (2005). Also the teat length was determined lower than the value reported by Milerski et al. (2006) in dairy breeds and by Izadifard and Zamiri (1997) in Iranian fat tail breeds. According to the age groups, the udder circumference, teat length and distance between teats were found to be the highest in 5+ years age when compared to the other age groups. These findings obtained in our study were similar with Unal et al. (2008a) and Prpic et al. (2013).

A negative correlation was found between the lactation length and milk fat content in Morkaraman $(\mathrm{p}<0.05, \mathrm{r}=-0.447)$. In addition, positive correlation was found between the lactation length and protein content in milk 
$(\mathrm{p}<0.05 ; \mathrm{r}=0.519)$. When the relationship between udder characteristics and milk yield in Morkaraman was examined, a positive correlation was found between udder depth and lactation milk yield $(\mathrm{p}<0.05, \mathrm{r}=0.425)$. There were a high positive correlation between udder depth and lactation milk yield $(\mathrm{p}<0.01 ; \mathrm{r}=0.631)$, lactation length $(\mathrm{p}<0.05, \mathrm{r}=0.606)$ and daily average milk yield $(\mathrm{p}<0.05, \mathrm{r}=0.562)$ in Awassi. Similar to this study, Snowder and Glimp (1991) in Rambouillet X Finn-Dorset sheep, Perez Linarez et al. (1984) in Mancha, Izadifard and Zamiri (1997) in
Mehraban and Ghezel, Emediato et al. (2008) in Bergamasca reported similar correlations. In contrast to Morkaraman, positive correlation was found between udder circumference and lactation milk yield and daily average milk yield and also between udder length and lactation milk yield and daily average milk yield in Awassi. Furthermore, in contrast to the Awassi, there was a positive correlation between udder depth and SNF $(\mathrm{p}<0.05 ; \mathrm{r}=0.536)$, protein $(\mathrm{p}<0.05 ; \mathrm{r}=0.570)$ and lactoz $(\mathrm{p}<0.05 ; \mathrm{r}=0.497)$ in the Morkaraman.

Table 3. Coefficients of phenotypic correlation among some milk contenents and udder traits in Morkaraman

\begin{tabular}{lccccccccccc}
\hline & Fat & SNF & Protein & Lactose & LMY & LL & DMY & UC & UL & HR & UW \\
\hline SNF & -0.082 & & & & & & & & & & \\
Protein & -0.281 & $0.979^{* * *}$ & & & & & & & & & \\
Lactoz & 0.069 & $0.988^{* * *}$ & $0.938^{* * *}$ & & & & & & & & \\
LMY & -0.145 & 0.071 & 0.097 & 0.050 & & & & & & & \\
LL & $-0.447^{*}$ & 0.107 & 0.193 & 0.038 & $0.731^{* *}$ & & & & & & \\
DMY & 0.186 & -0.145 & -0.179 & -0.114 & $0.679^{* *}$ & 0.030 & & & & & \\
UC & -0.049 & 0.445 & 0.438 & 0.440 & 0.201 & -0.039 & 0.313 & & & & \\
UL & -0.191 & 0.253 & 0.282 & 0.225 & 0.265 & 0.134 & 0.115 & 0.052 & & & \\
HR & -0.049 & -0.311 & -0.286 & -0.319 & -0.093 & 0.118 & -0.332 & -0.073 & 0.148 & & \\
UW & -0.167 & 0.447 & 0.460 & 0.422 & 0.316 & 0.091 & 0.334 & $0.481^{* *}$ & $0.540^{*}$ & -0.417 & \\
UD & -0.271 & $0.536^{*}$ & $0.570^{*}$ & $0.497^{*}$ & $0.425^{*}$ & 0.270 & 0.296 & $0.701^{* *}$ & 0.279 & -0.205 & $0.671^{* *}$ \\
\hline SNF: Sold
\end{tabular}

SNF: Solid non fat, LMY: Lactation Milk Yield, LL: Lactation length, UC: Udder circumference, UL: Udder length, HR: Height at rump, UW: Udder width, UD: Udder depth, *: $\mathrm{P}<0.05$, **:P<0.01, ***:P<0.001,

Table 4. Coefficients of phenotypic correlation among some milk contenenets and udder traits in Awassia

\begin{tabular}{lccccccccccc}
\hline & Fat & SNF & Protein & Lactose & LMY & LL & DMY & UC & UL & HR & UW \\
\hline SNF & -0.049 & & & & & & & & & & \\
Protein & -0.347 & $0.954^{* * *}$ & & & & & & & & & \\
Lactoz & 0.176 & $0.975^{* * *}$ & $0.862^{* *}$ & & & & & & & & \\
LMY & 0.094 & 0.199 & 0.162 & 0.219 & & & & & & & \\
LL & -0.275 & 0.462 & $0.519^{*}$ & 0.397 & $0.593^{*}$ & & & & & & \\
DMY & 0.189 & 0.073 & 0.015 & 0.115 & $0.976^{* *}$ & 0.413 & & & & & \\
UC & 0.103 & 0.241 & 0.199 & 0.262 & $0.670^{* *}$ & $0.517^{*}$ & $0.629^{* *}$ & & & & \\
UL & -0.377 & -0.391 & -0.250 & -0.468 & $0.566^{*}$ & 0.290 & $0.581^{*}$ & $0.357^{*}$ & & & \\
HR & -0.316 & -0.298 & -0.186 & -0.365 & -0.355 & -0.113 & -0.348 & -0.143 & 0.236 & & \\
UW & 0.097 & 0.429 & 0.375 & 0.445 & 0.454 & 0.464 & 0.396 & $0.833^{* *}$ & 0.051 & -0.119 & \\
UD & -0.147 & 0.198 & 0.235 & 0.162 & $0.631^{* *}$ & $0.606^{*}$ & $0.562^{*}$ & $0.767^{* *}$ & 0.336 & -0.237 & $0.697^{* *}$ \\
\hline
\end{tabular}

SNF: Solid non fat, LMY: Lactation Milk Yield, LL: Duration of lactation, UC: Udder circumference, UL: Udder length, HR: Height at rump, UW: Udder width, UD: Udder depth, *: $\mathrm{P}<0.05, * *: \mathrm{P}<0.01, * * *: \mathrm{P}<0.001$,

There was more correlation between udder characteristics and lactation traits in Awassi compared to Morkaraman. The reason for this situation can be explained as the milking character of the Awassi. Similar to the studies conducted in different breeds (Kominakis et al., 2009; Prpic et al. 2013), there was a positive correlation between udder traits (udder depth, udder circumference and udder width) in both breeds $(\mathrm{p}<0.05 ; \mathrm{r}=0.357$ $0.833)$. 


\section{Conclusion}

There was more positive correlation between udder characteristics and lactation traits in Awassi compared to Morkaraman. Although udder type had no effect on lactation characteristics and udder measurement, lactation characteristics and udder measurement were higher in I udder type. So, I udder type may be more suitable for machine milking in terms of udder size. New studies on the rate of milking from the alveoli and cistern area in machine milking are recommended.

\section{References}

Akdag, F., Teke, B., Ugurlu, M., Onyay, F.B., Kocak, O. and Demir, H. 2018. Udder types and associated traits affect milk composition and subclinical mastitis in Karayaka sheep. Indian Journal of Animal Sciences, 88(10), 11861192.

Al-Jundi, A. 2010. Milk yield and lamb growth of Syrian-Awassi sheep graze on cereal and cereal-legume mixture forages. MSc. Thesis. Çukurova Unversity, Institute of Natural and Applied Science. Adana. 66 pages

Alkass, J.E and Akreyi I.A.I. 2015. Milk production of Awassi and Karadi ewes raised under farm conditions. Advanced Journal of Agricultural Research, Vol. 4(01), 008-013.

Altincekic, S.Ö. and Koyuncu, M. 2011. Kıvırcık, Tahirova ve Karacabey Merinosu koyunlarında meme morfolojisi özelliklerinde linear puanlama ve meme ölçüleri arasındaki ilişkiler. Journal of the Faculty of Veterinary Medicine, Kafkas University, 17: 71-76.

Celik, S. and Ozdemir, S. 2003. The variations of some chemical and physicochemical parameters of Morkaraman sheep milk during lactation. Journal of the Faculty of Agriculture, 34(3), 263-268.

Dag, B. and Ugur, Z. 2004. Relationships among udder traits and milk production in unimproved Awassi sheep. Journal of Animal and Veterinary Advances. 3,730-735.

de la Fuente, L.F., Fernandez, G. and San Primitivo, F. 1996. A linear evaluation system for udder traits in dairy sheep, Livestock Production Science 45, 171-178.

Dogan, Ş., Aytekin, İ., and Boztepe, S., 2013. Anadolu Merinosu koyunlarında meme tipleri ile meme özellikleri, süt verimi ve bileşenleri arasındaki ilişkiler. Tekirdağ Ziraat Fakültesi Dergisi, 10(2), 58-69.
Dzidic, A., Kaps, M., and Bruckmaier, R.M. 2004. Machine milking of Istrian dairy crossbreed ewes: udder morphology and milking characteristics. Small Ruminant Research, 55(1-3), 183-189.

Emediato, R.M.S., Siqueira, E.R., Stradiotto, M.M., Maest'a, S.A. and Fernandes S. 2008. Relationship between udder measurements and milk yield in Bergamasca ewes in Brazil. Small Ruminant Research 75, 232-235.

Epstein, H., 1985. The Awassi Sheep with special reference to the improved dairy type. FAO Animal Production and Health Paper, Food and Agriculture Organization of the United Nations. Rome. 57

Gursu, G. and Aygün, T. 2014. Some characteristics of milk yield in Awassi ewes maintained at village conditions. Journal of Advanced Agricultural Technologies 1(1), 19-23.

Izadifard, J., and Zamiri, M.J. 1997. Lactation performance of two Iranian fat-tailed sheep breeds. Small Ruminant Research, 24(2), 6976.

Kaygısız, A. and Dag, B. 2017. Elit İvesi koyunlarında meme tipinin ve bazı çevre faktörlerinin süt verimine etkisi. Kahramanmaraş Sütçü İmam Üniversitesi Doğa Bilimleri Dergisi, 20(4): 344-349.

Kırmızıbayrak, T., Aksoy, A.R., Saatçı, M. and Tilki, M. 2005. Tuj ve Morkaraman koyunların süt verimi ve meme özellikleri ile bu özellikler arasındaki ilişkiler. Kafkas Univ Vet Fak Derg, 11(1), 11-15.

Kocak, S., Celikeloglu, K., Celik, H. A., Bozkurt, Z. and Tekerli, M. 2018. Some lactation traits, somatic cell count and udder characteristics of Pirlak sheep. Eurasian Journal of Veterinary Sciences, 34(1), 36-42.

Kominakis, A. P., Papavasiliou, D. and Rogdakis, E. 2009. Relationships among udder characteristics, milk yield and, non-yield traits in Frizarta dairy sheep. Small Ruminant Research, 84(1-3), 82-88.

Kucuk, M., Ozturk, Y. and Bayram, D. 2000. Yar1 entansif şartlarda Hamdani, Karagül, ve Morkaraman koyunlarının süt verimi özelliklerinin karşılaştırılması. Yüzüncü Yı1 Üniversitesi Veteriner Fakültesi Dergisi. 11(1), 44-48.

Kukovics, S. Molnar, A., Ábrahám, M., Németh, T, and Komlósi, I. 2006. Effects of udder traits on the milk yield of sheep. Archives Animal Breeding, 49(2), 165-175. 
Macit, M. and Aksoy, A. 1996. Atatürk Üniversitesi tarım işletmesinde yetiştirilen İvesi ve Morkaraman koyunlarının yarı entansif şartlarda bazı önemli verim özellikleri bakımından karşılaştırılması. Tübitak Turkish Journal of Veterinary and Animal Sciences, 20, 465-470.

Makovický P., Margetín M. and Makovicky P. 2017. Estimation of genetic and phenotypic parameters for udder morphology traits in different dairy sheep genotypes. Acta Universitatis Agriculturae et Silviculturae Mendelianae Brunensis 65, 105- 10.

Makovicky P., Nagy M. and Makovický P. 2014. The comparison of ewe udder morphology traits of improved Valachian, Tsigai, Lacaune breeds and their crosses. Mljekarstvo 64: 86-93.

Martinez M.E., Calderon C., de la Barra R., de la Fuente L.F. and Gonzalo C. 2011. Udder morphological traits and milk yield of Chilota and Suffolk down sheep breeds. Chilean Journal of agricultural Research 71(1), 90-95.

Milerski M., Margetin M., Capistrak A., Apolen D., Spanik J. and Oravcova M. 2006. Relationships between external and internal udder measurements and the linear scores for udder morphology traits in dairy sheep. Czech Journal of Animal Science 51(9): 383-90.

Ozbey, O. and Akcan, A. 2000. Production performance of Akkaraman, Morkaraman and Awasi sheep under semi-intensive conditions I. Fertility and milk production characteristics. Veteriner Bilimleri Dergisi, 16(1), 109-120.

Ozyurek, S., Dogan, T., Mustafa, Y. and Nurinisa, E. 2018. Determination of morphological and linear udder traits in Morkaraman, Tuj and Awassi sheep. Indian J. Anim. Res., 52 (83), 424-430.

Perez Linarez, J., Gomes Gil, J.L. and Garcia Lopez, J., 1984. A study on udder morphology in Mancha ewes. In: Sever Cuesta (Editor), III Symposium International de Dvdeno Mecanico de Pequenos Ruminates, Volladolid, Espana, May 1984, Madrid, Spain (abstracted in Animal Breeding Abstract, 53 (1984)

Prpic, Z., Mioe, B., Vnuèec, I., Drzaic, V. and Pavic, V. 2013. Non-genetic factors of udder morphology traits in Istrian ewes. Mljekarstvo $63,72-80$

Sagi, R. and Morag, M. 1974. Udder conformation, milk yield and milk fractionation in the dairy ewes. Annales de Zootechnie 23, 185-92.
Sahan, N., Say, D., and Kacar, A. 2005. Changes in chemical and mineral contents of Awassi ewes' milk during lactation. Turkish Journal of Veterinary and Animal Sciences, 29 (3), 589-593.

Seker, İ., Selim, K. and Bayraktar, M. 2000. İvesi ve Ost-FrizXİvesi Melezi (F1) koyunlarda linear meme özellikleri ve bunlar ile süt verimi arasındaki ilişkiler. Lalahan Hayvancılık Araştırma Enstitüsü Dergisi, 40(2), 1-11.

Snowder, G.D. and Glimp, H.A., 1991. Influence of breed, num- ber of suckling lambs, and stage of lactation on ewe milk production and lamb growth under range conditions. Journal of Animal Science, 69, 923-930.

Talafha, A.Q. and Ababneh, M.M. 2011. Awassi sheep reproduction and milk production: review. Tropical Animal Health Production, 43(7), 1319-1326.

Unal, N., Akçapınar, H., Atasoy, F., Yakan, A. and Ugurlu M. 2008a. Bafra koyunlarında bazı meme özellikleri ve kuzularda büyüme ile bu özelliklerin farklı süt kontrol yöntemleriyle tespit edilen süt verimi ve sağım özellikleriyle fenotipik korelasyonları Ankara Üniversitesi Veterinerlik Fakültesi Dergisi, 55, 117-124

Unal, N., Akcapinar, H., Atasoy, F., Yakan, A. and Ugurlu, M. 2008b. Milk yield and milking traits measured with different methods in Bafra sheep. Revue de Medecine Veterinaire, 159(10), 497-501.

URL-1, www.tuik.gov.tr. 09.09.2019

Ustuner, H., and Ogan, M.M. 2013. Main productive performance of Awassi sheep in the Central Anatolian Region of Turkey. Turkish Journal of Veterinary and Animal Sciences, 37(3), 271-276.

Yakan, A., 2012. Koyun ve keçilerde süt verim kontrol yöntemleri ve laktasyon süt veriminin hesaplanmasi. Adana Veteriner Kontrol Enstitüsü Müdürlüğü Dergisi 2,18-23.

Yildız A. and Yildız N. 2002. Ceylanpınar Tarım İşletmesi'nde yetiştirilen İvesi koyunlarının süt verimi ve laktasyon süresi. Yüzüncü Y1l Üniversitesi Veteriner Fakültesi Dergisi, 13(12), 117-121.

Yılmaz, O., Çak, B., and Bolacali, M. 2011. Effects of lactation stage, age, birth type and body weight on chemical composotion of Red Karaman sheep milk. Kafkas Üniversitesi Veterinerlik Fakültesi Dergisi, 17(3), 383-386. 